\title{
Endometrial cyst and its changes during pregnancy - a narrative review of the literature
}

\section{Torbiel endometrialna i jej zmiany w trakcie ciąży - przegląd piśmiennictwa}

\author{
Jakub Młodawski ${ }^{1,2}$, Marta Mlodawska ${ }^{1}$, Mariusz Malmur², Justyna Płusajska ${ }^{1,2}$, Grzegorz Świercz \\ Marek Sikorski ${ }^{1}$ \\ ${ }^{1}$ Collegium Medicum, Jan Kochanowski University, Kielce, Poland \\ Head of the Collegium: Prof. Marianna Janion MD, PhD \\ ${ }^{2}$ Clinic of Obstetrics and Gynaecology, Provincial Combined Hospital, Kielce, Poland \\ Head of the Clinic: Grzegorz Swiercz MD, PhD
}

Key words: endometrial cyst, chocolate cyst, endometrioma, pregnancy.

Słowa kluczowe: torbiel endometrialna, torbiel czekoladowa, endometrioma, ciąża.

\begin{abstract}
Endometrioma of the ovary (chocolate cyst) is one of the most common tumours of the appendages diagnosed in pregnant patients. In approximately $12 \%$ of pregnancies with diagnosed ovarian endometriomas, the process of decidualization, i.e. tumour secretory transformation, occurs under the influence of high progesterone concentrations. Decidualized endometrioma is a benign lesion, but its ultrasound appearance imitates a malignancy; therefore, knowledge of the process and diagnostic possibilities is extremely important for the clinician, and it may limit the number of surgical interventions in pregnant patients. This review discusses the decidualization of endometriosis as well as the ultrasound and biochemical diagnostics of this entity.
\end{abstract}

\section{Streszczenie}

Torbiel endometrialna jajnika (torbiel czekoladowa) jest jednym z najczęstszych guzów przydatków diagnozowanych u pacjentek ciężarnych. W ok. $12 \%$ przypadków w ciąży dochodzi do procesu decydualizacji zmiany, tj. przemiany sekrecyjnej tkanki guza pod wpływem dużego stężenia progesteronu. Zmiana, która uległa decydualizacji, histologicznie ma łagodny charakter, jednak obraz ultrasonograficzny może imitować raka jajnika. Znajomość procesu decydualizacji ma duże znaczenie dla klinicystów, ponieważ może ograniczyć liczbę interwencji chirurgicznych u pacjentek ciężarnych. W niniejszym przeglądzie zostało omówione zjawisko decydualizacji torbieli endometrialnej w ciąży, jak również możliwości diagnostyki ultrasonograficznej i biochemicznej.

\section{Endometriosis in the population of pregnant patients}

Endometriosis is associated with the presence of glands and endometrial stroma outside the uterine cavity. The disease affects about $10 \%$ of women of reproductive age, $50 \%$ of patients diagnosed for infertility, and $70 \%$ diagnosed for chronic abdominal pain $[1,2]$. The highest prevalence of endometriosis occurs in patients between 25 and 35 years of age [3]; this is also the age of peak procreation in Europe. Endometriosis affects the quality of life of patients and their procreative plans. The most frequent location of lesions is the ovary (67\% of patients with laparoscopically confirmed endometriosis) [4]. Ovarian endometriosis most often takes the form of a cyst - endome- trioma (so-called "chocolate cyst"). Given the average age of procreation in Europe, the age range of patients with the highest prevalence of endometriosis, and the tendency to relapse after treatment, the coexistence of pregnancy and endometriosis is often observed in clinical practice [5].

\section{Pregnancy in patients with endometriosis}

Pain, infertility or subfertility are typical symptoms of endometriosis. Pain in patients suffering from endometriosis during pregnancy usually disappears or alleviates, and endometrial lesions decrease in size [6]. Factors influencing changes in endometrial lesions are the period of gestation (the chance of regression of the lesion increases with the progression of preg- 
nancy) and the size of the lesion (greater tendency to complete regression in the case of diameter $<20 \mathrm{~mm}$ ). The literature also describes histological features of endometriosis foci increasing susceptibility to regression under the influence of gestagens [6]. However, patients who become pregnant have an increased risk of certain obstetric complications compared to pregnant patients without diagnosed endometriosis. Such complications include miscarriage - OR (odds ratio) $=1.76$ (95\% CI: 1.44-2.15), ectopic pregnancy - OR $=2.70$ (95\% CI: $1.09-6.72)$, pre-eclampsia $(\mathrm{OR}=1.18$, 95\% CI: 1.01-1.39), gestational diabetes (RR (relative risk) $=1.26$, 95\% CI: 1.03-1.55), gestational cholestasis $(\mathrm{OR}=4.87,95 \% \mathrm{CI}: 1.85-12.83)$, placenta previa $(\mathrm{OR}$ $=3.31,95 \%$ CI: 2.37-4.63), antepartum haemorrhage $(\mathrm{OR}=1.69,95 \% \mathrm{CI}: 1.38-2.07)$, and antepartum hospital admissions (OR $=3.18,95 \% \mathrm{CI}: 2.60-3.87)$. There is also a higher risk of neonatal complications such as preterm premature rupture of membranes $(\mathrm{OR}=2.33$, 95\% CI: 1.39-3.90), stillbirth (OR = 1.29, 95\% CI: 1.10 $1.52)$, preterm birth $(\mathrm{OR}=1.70,95 \% \mathrm{CI}: 1.40-2.06)$, small for gestational age $(<10$ percentile) $(\mathrm{OR}=1.28$, 95\% CI: 1.11-1.49), and admission to a neonatal intensive care unit $(\mathrm{OR}=1.39,95 \% \mathrm{CI}$ : $1.08-1.78)$ [7-11]. The literature also presents cases of surgical complications of visceral endometriosis such as intestinal perforation, appendicitis, rapture of endometriomas and fallopian tubes, or spontaneous pneumothorax [6].

\section{Endometrioma during pregnancy and decidualization process}

The occurrence of endometrioma in the population of pregnant patients is estimated at approx. $0.5 \%$ [12]. Population studies indicate that ultrasound examination of the ovaries with a vaginal probe in the $1^{\text {st }}$ trimester of pregnancy during 1 st trimester prenatal examinations $\left(11-13^{+6}\right.$ weeks of gestation) allows visualization in approx. $11 \%$ of patients with adnexal tumours (taking into account only complex and simple cysts with a diameter greater than $5 \mathrm{~cm}$ ) [13]. In the cohort presented in a study among patients who underwent enucleation of an ovarian cyst during pregnancy due to pain, suspected cancer, or the patient's request, histopathological diagnosis of endometrioma was made in $24.2 \%$ of cases and was the second most common diagnosis after dermoid cysts (36.4\%) [13].

Ultrasound diagnosis of an endometrial cyst is rather straightforward: unilocular cyst with low-level homogenic internal echoes ("ground glass"), clear demarcation from ovarian parenchyma, increased through-transmission of acoustic beam, usually with no solid areas and papillary projections (Figure 1). Such an image of endometrioma is not universal, but it affects up to $80 \%$ of tumours [14].

The goal of endometrioma treatment outside pregnancy is to reduce pain and prevent complications related to rupture and torsion of the ovary, as well as to

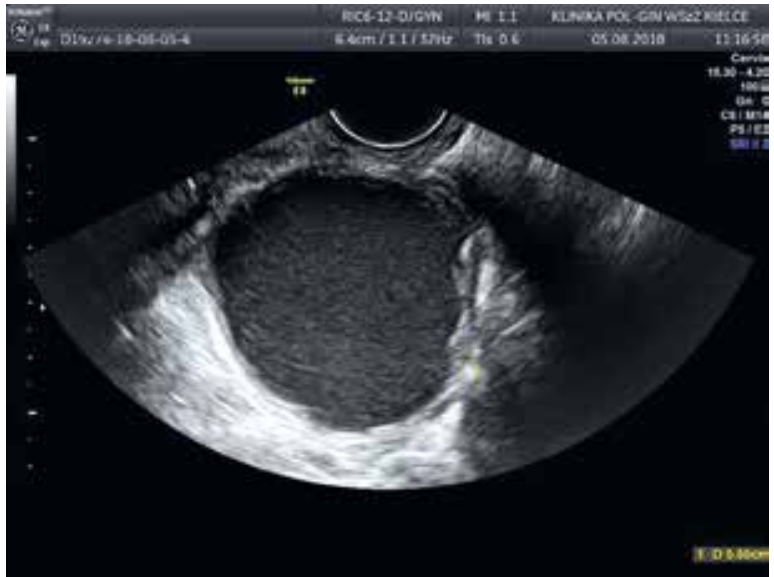

Figure 1. Endometrioma with typical ultrasound image

treat infertility while maintaining ovarian reserve. An important element is also the exclusion of cancer. Endometriosis is associated with a small increased risk of ovarian cancer (standardized incidence ratio (SIR) 1.76, 95\% CI: 1.47-2.08). This relationship is mainly related to endometrioid (SIR $=3.12$, 95\% CI: 2.15-4.38) and clear cell (SIR $=5.17,95 \%$ CI: 3.20-7.89) cancer $[15,16]$. Patients should be informed about the increased risk of ovarian cancer. The increase in life-time absolute risk of ovarian cancer for patients with endometriosis is small and amounts to $1.8 \%$ (in the general population the risk is 1.31\%) [17]. A definite histological diagnosis can only be made after surgical removal of cysts. Surgical treatment, despite the advantages of direct evaluation of the tissue collected, is limited due to potential postoperative complications [18, 19].

Medical treatment is an alternative to surgical treatment. Commonly used therapies are progestogens alone, estrogen-progestin contraceptive pills or $\mathrm{GnRH}$ agonists. This treatment is aimed at decidualizing endometriotic foci (secretory transformation), followed by ectopic endometrial atrophy. This process reduces bleeding from ectopic endometrial lesions and reduces the local inflammatory reaction, and thus the patient's pain. Despite the lack of access to the abdominal cavity and the histological examination of the lesion, such a procedure avoids the risk associated with the surgery and its potential complications.

Pregnancy is a physiological condition associated with elevated progesterone levels. It is initially produced by the corpus luteum. Later, between the $7^{\text {th }}$ and $10^{\text {th }}$ week of pregnancy, the placenta becomes its primary production site. At the beginning of pregnancy, its serum concentration ranges from 8 to $48 \mathrm{ng} / \mathrm{ml}$, while its concentration in the serum is between 100 and $200 \mathrm{ng} / \mathrm{ml}$ during full-term pregnancy [20]. On the one hand, high progesterone concentrations in pregnancy result in the reduction of the patient's pain, but may lead to the initiation of the process of endometrioma decidualization, i.e. secretory transformation. The pro- 
cess itself has no implications for the patient's health but is a diagnostic challenge for the doctor. Knowledge about this process is essential because it can imitate ovarian cancer in ultrasound. The process of endometrioma growth in pregnancy concerns about $20 \%$ of cases. Tumour growth is not always associated with decidualization, and ultrasound enlargement may also occur as a result of abscess formation or rupture [12]. In half of the cases the size of the endometrioma is reduced, and in 28\% it remains unchanged [12].

\section{Ultrasound features of the decidualization of endometriomas}

Decidualized endometrioma has no pathognomonic ultrasound features. In the initial stage of decidualization, an increase in the echogenicity of the contents of the inside of the cyst can be observed (Figure 2); with time, the most disturbing symptom for an ultrasound examiner is papillary projection into the lumen of the cyst (Figure 3). In the literature, we can find mainly case series. On this basis, researchers are trying to establish common diagnostic features that help differentiate endometrioma decidualization from ovarian cancer. However, differentiation is not easy, especially in the case of de novo diagnosis in patients whose ovarian lesions were not diagnosed in the first trimester of pregnancy. Most of the tumours subject to decidualization present in the ultrasound the morphology of unilocular cysts with solid components $(52 \%)$, and in $39 \%$ they present the multilocular form with solid components. The number of papillary outgrowths in the lumen of the cyst varies significantly between tumours; however, most often these are 3 papillary projections (33\% of decidualized endometriomas), and they have a maximum diameter between $6 \mathrm{~mm}$ and $79 \mathrm{~mm}$ and a height of 3-33 $\mathrm{mm}$. Almost all the projections show colour or power Doppler signals (94\%); this signal is usually well expressed (colour score $3-72 \%$ ) (Figures 4 A, B). A feature that seems to be characteristic is the smooth surface of papillary projections (82\% of decidualized endometriomas) (21) (Figure 3). Papillary projections are clearly visible in macroscopic preparations of excised lesions (Figure 5). Commonly used in the medical community, ultrasound diagnostic models of ovarian lesions such as Simple Rules (International Ovarian Tumour Analysis - IOTA) or mixed models also using other clinical data (including Ca125 concentration) such as ADNEX (IOTA) or RMI (risk malignancy index) are not standardized to the population of pregnant patients, which may lead to a high false positive ratio.

The diagnostics of endometrioma decidualization is a challenge for the ultrasound examiner. In one study, 18 cysts diagnosed postoperatively as endometrioma decidualization were subjected to an ultrasound evaluation of the lesion. In $56 \%$ of the cysts, the ultrasound examiner was not able to assess the malig-

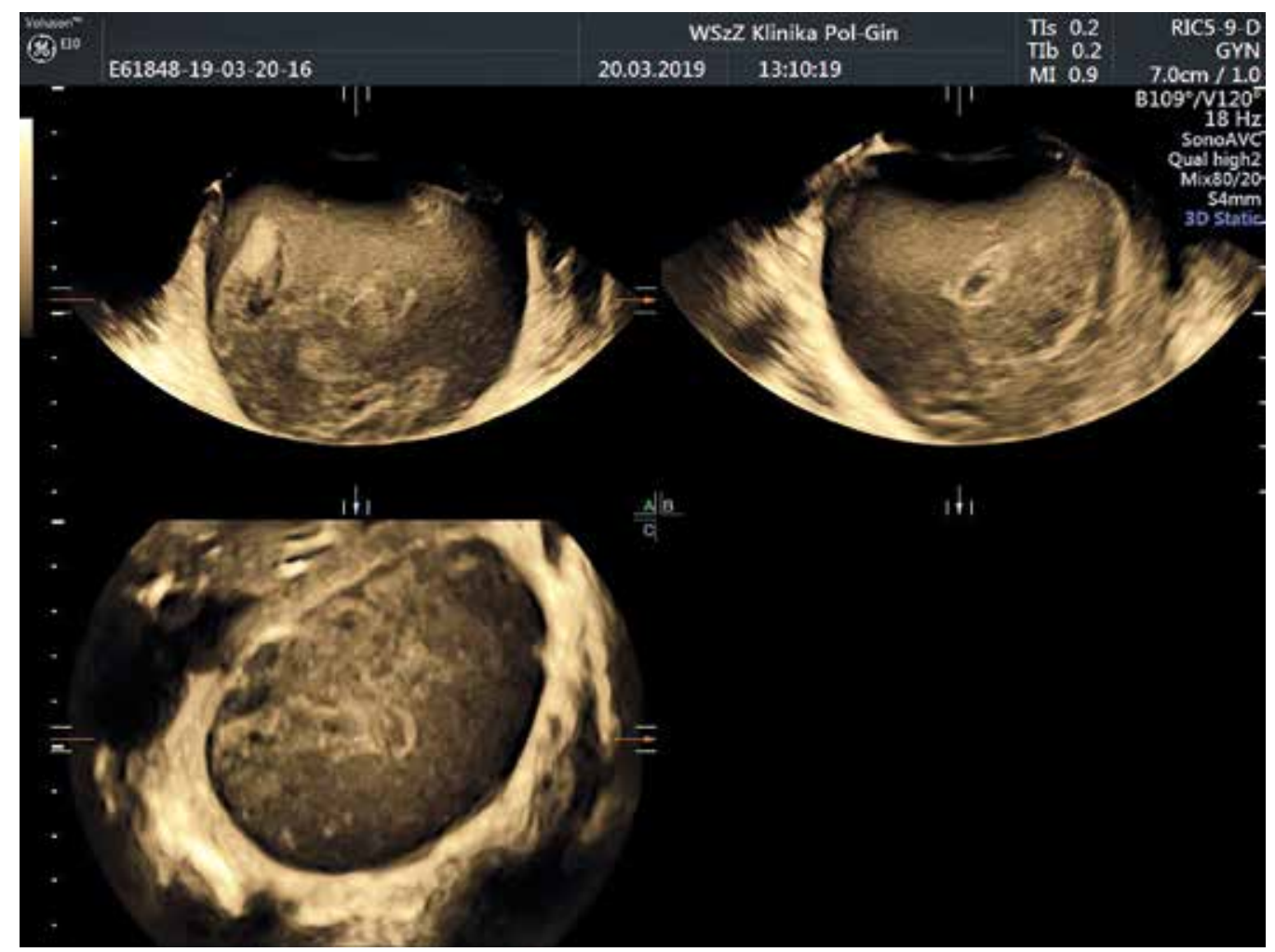

Figure 2. The decidualization process begins. Ultrasound "density" of the cyst contents 


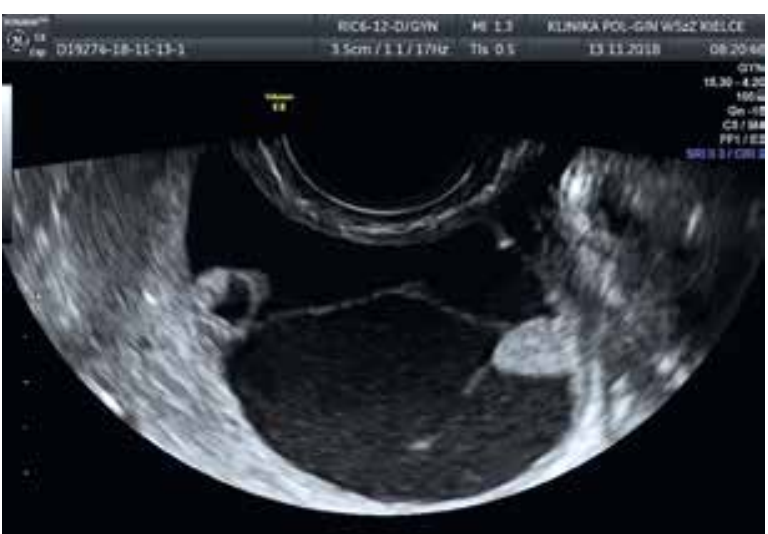

Figure 3. Decidualized endometrioma. Smooth surface of papillary projections

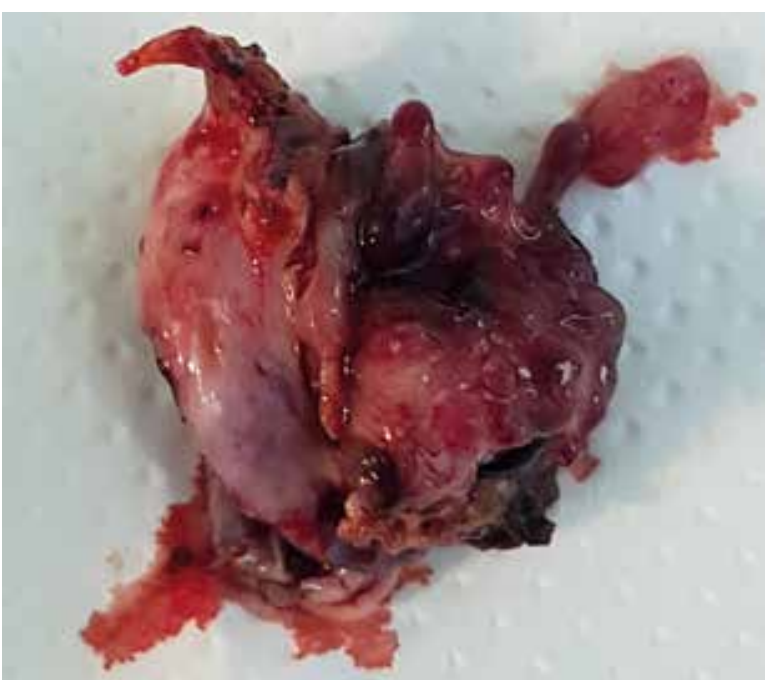

Figure 5. Macroscopic preparation of decidualized endometrioma

nancy potential, and only in $17 \%$ was the examiner sure that the lesion was benign. Borderline tumour was suspected in $44 \%$ of cases [21].

In such a situation, the most valuable diagnostic clue seems to be a typical image of endometrioma in an ultrasound examination before pregnancy or in the first trimester, before the decidualization process begins.

\section{Serum markers in the process of differentiating malignant changes from decidualized endometriomas}

In the process of differentiation of decidualized endometrioma and ovarian cancer, tumour markers are limited of use. Before pregnancy, in patients suffering from endometriosis, the concentration of the Ca125 marker is usually already slightly elevated or within the upper limits of the normal range, and is characterized by a greater population spread (median

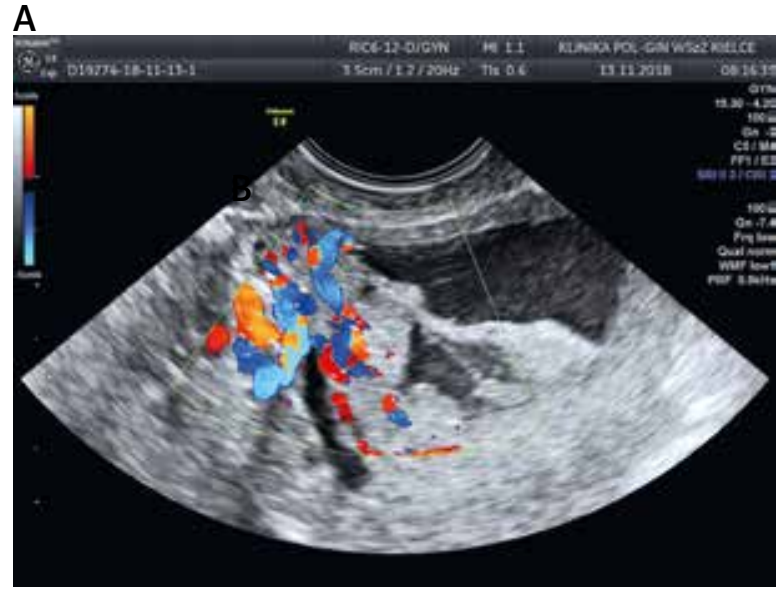

B

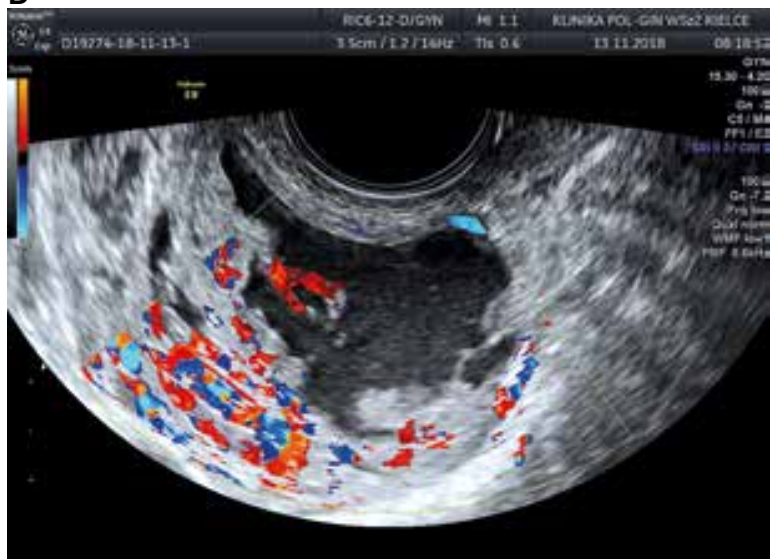

Figure 4. A, B - Papillary outgrowths with intensive Doppler colour score 3 signal

$-44 \mathrm{U} / \mathrm{ml}, 75^{\text {th }}$ percentile $-85 \mathrm{U} / \mathrm{ml}$ ) and significantly higher than in the case of other benign cysts of the ovary (median - $15 \mathrm{U} / \mathrm{ml}, 75^{\text {th }}$ percentile $-24 \mathrm{U} / \mathrm{ml}$ ) [14]. Serum Ca125 levels are elevated in most ovarian cancer cases. Meta-analysis shows an overall sensitivity and specificity (Ca125 > 35 U/ml) of 78\% [22]. However, the sensitivity of the test depends on the stage of the ovarian cancer and the type of cancer (it is lower in mucous and clear cell carcinomas) [23, 24]. The use of a pregnancy test at the cut-off point for the premenopausal population may result in a significant reduction in specificity and an increase in the false positive ratio. Ca125 may be useful in differentiating ovarian cancer from a benign lesion after 15 weeks of gestation until the moment of delivery; at this time, significantly elevated levels (> $1000 \mathrm{U} / \mathrm{ml}$ ) usually suggest a proliferative disease, but concentrations of lower order of magnitude (100-150 U/ml) are not rare at this stage of pregnancy and do not provide additional diagnostic information [25].

Concentrations of other cancer markers that may be helpful in the diagnosis of ovarian cancer in pregnancy, i.e. carcinoembryonic antigen (CEA), 
$\alpha$-fetoprotein (AFP), and human chorionic gonadotropins (hCG), are usually increased during pregnancy and are characterized by high variability during pregnancy; additionally, their concentrations may be affected by maternal or foetal complications [25]. In contrast, the median HE4 concentration during pregnancy is lower compared to non-pregnant patients in reproductive age $[26,27]$.

All cancer markers have limited usefulness in differentiating between endometrioma decidualization and ovarian cancer.

\section{Conclusions}

Endometrioma decidualization is not a common process among patients with diagnosed endometrioma, but it is a process that every clinician should know about, given the benign nature and the ultrasound image imitating ovarian cancer. In our opinion, ovaries should be examined ultrasonographically for pathological changes in the first trimester in pregnancy. The presentation of a typical endometrial cyst image supports the diagnostic process of decidualization in the second trimester of pregnancy. Due to the small number of cases described in the literature, there are currently no standards (expectant management/surgical procedure) in the case of patients with endometrial decidualization image; each patient requires an individualised approach. Further research is needed to search for ultrasound and biochemical markers of the decidualization process.

\section{Acknowledgments}

Project financed under the program of the Minister of Science and Higher Education called "Regional Initiative of Excellence" in the years 2019-2022, project no. 024/RID/2018/19, amount of financing 11999000.00 zł.

\section{Conflict of interest}

The authors declare no conflict of interest.

\section{References}

1. Lin KY, Chang CY, Lin WC, Wan L. Increased risk of endometriosis in patients with endometritis - a nationwide cohort study involving 84,150 individuals. Ginekol Pol 2020; 91: 193-200.

2. Gica N, Panaitescu AM, Iancu G, Botezatu R, Peltecu G, Gica C. The role of biological markers in predicting infertility associated with non-obstructive endometriosis. Ginekol Pol 2020; 91: 189-192.

3. Missmer SA, Hankinson SE, Spiegelman D, Barbieri RL, Marshall LM, Hunter DJ. Incidence of laparoscopically confirmend endometriosis by demographic, anthropometric, and lifestyle factors. Am J Epidemiol 2004; 160: 784.

4. Audebert A, Petousis S, Margioula-Siarkou C, Ravanos K, Prapas N, Prapas Y. Anatomic distribution of endome- triosis: a reappraisal based on series of 1101 patients. Eur J Obstet Gynecol Reprod Biol 2018; 230: 36.

5. Han S, Lee H, Kim S, Joo J, Suh D, Kim K, Lee K. Risk factors related to the recurrence of endometrioma in patients with long-term postoperative medical therapy. Ginekol Pol 2018; 89: 611-617.

6. Leeners B, Damaso F, Ochsenbein-Kölble N, Farquhar C. The effect of pregnancy on endometriosis-facts or fiction? Hum Reprod Update 2018; 24: 290-299.

7. Lalani S, Choudhry AJ, Firth B, Bacal V, Walker M, Wen SW, Singh S, Amath A, Hodge M, Chen I. Endometriosis and adverse maternal, fetal and neonatal outcomes, a systematic review and meta-analysis. Hum Reprod 2018; 33: 1854-1865.

8. Warzecha D, Pietrzak B, Szymusik I, Smiech Z, Wielgos M. Should the patients with endometriosis be treated as a risk group of pregnancy complications? Single center experience and literature review and literature review. Ginekol Pol 2020; 91: 383-388.

9. Miura M, Ushida T, Imai K, Wang J, Moriyama Y, NakanoKobayashi T, Osuka S, Kikkawa F, Kotani T. Adverse effects of endometriosis on pregnancy: a case-control study. BMC Pregnancy Childbirth 2019; 19: 373.

10. Zupi E, De Felice G, Conway G, Martire F, Exacoustos C, Centini G, Patrizi L, Piccione E, Lazzeri L. From endometriosis to pregnancy: which is the "road-map"? J Endometr Pelvic Pain Disord 2017; 9: 252-262.

11. Saraswat L, Ayansina DT, Cooper KG, Bhattacharya S, Miligkos D, Horne AW, Bhattacharya S. Pregnancy outcomes in women with endometriosis: a national record linkage study. BJOG 2017; 124: 444-452.

12. Ueda Y, Enomoto T, Miyatake T, Fujita M, Yamamoto R, Kanagawa T, Shimizu H, Kimura T. A retrospective analysis of ovarian endometriosis during pregnancy. Fertil Steril 2010; 94: 78-84.

13. Yazbek J, Salim R, Woelfer B, Aslam N, Lee CT, Jurkovic D. The value of ultrasound visualization of the ovaries during the routine 11-14 weeks nuchal translucency scan. Eur J Obstet Gynecol Reprod Biol 2007; 132: 154-158.

14. Van Holsbeke C, Van Calster B, Guerriero S, Savelli L, Paladini D, Lissoni AA, Czekierdowski A, Fischerova D, Zhang J, Mestdagh G, Testa AC, Bourne T, Valentin L, Timmerman D. Endometriomas: their ultrasound characteristics. Ultrasound Obstet Gynecol 2010; 35: 730-740.

15. Saavalainen L, Lassus H, But A, Tiitinen A, Härkki P, Gissler M, Pukkala E, Heikinheimo O. Risk of gynecologic cancer according to the type of endometriosis. Obstet Gynecol 2018; 131: 1095-1102.

16. Kornovski Y, Atanasova Y, Kostov S, Slavchev S, Yordanov AD. Endometriosis and risk of ovarian cancer. Oncol Clin Pract 2021; 17: 125-127.

17. Kvaskoff M, Horne AW, Missmer SA. Informing women with endometriosis about ovarian cancer risk. Lancet 2017; 390: 2433-2434

18. Nashibi R, Khosravi AD, Bakhtiary EE, Shiravi M. Evaluation of risk factors and the epidemiological pattern of nosocomial infection after gynaecological surgery in Ahvaz Imam Khomeini Hospital during the period 20112016. Medical Studies 2020; 36: 26-30.

19. Łabuzek M, Grochowska A, Mika M, Wojtaszek K. Subjective assessment of post-operative pain in patients hospitalised in surgical wards. Medical Studies 2019; 35: 100-107. 
20. Młodawski J, Rokita W, Młodawska M. Stosowanie progesteronu $\mathrm{w}$ zapobieganiu porodowi przedwczesnemu. Ginekol Perin Prakt 2018; 3: 85-92.

21. Mascilini F, Moruzzi C, Giansiracusa C, Guastafierro, F Savelli L, De Meis L, Epstein E, Timor-Tritsch IE, Clinical and ultrasound characteristics of decidualized endometriomas surgisurgically removed during pregnancy. Ultrasound Obstet Gynecol 2014; 44: 354-360.

22. Dodge JE, Covens AL, Lacchetti C, Elit LM, Le T, Devries-Aboud M, Fung-Kee-Fung M; Group Gynecology Cancer Disease Site. Preoperative identification of a suspicious adnexal mass: a systematic review and meta-analysis. Gynecol Oncol 2012; 126: 157-166.

23. Dorigo O, Berek JS. Personalizing CA125 levels for ovarian cancer screening. Cancer Prev Res 2011; 4: 13561359.

24. Rosenthal AN, Menon U, Jacobs IJ. Screening for ovarian cancer. Clin Obstet Gynecol 2006; 49: 433-447.

25. Sarandakou A, Protonotariou E, Rizos D. Tumor markers in biological fluids associated with pregnancy. Crit Rev Clin Lab Sci 2007; 44: 151-178.

26. Moore RG, Miller MC, Eklund EE, Lu KH, Bast RC Jr, Lambert-Messerlian G. Serum levels of the ovarian cancer biomarker HE4 are decreased in pregnancy and increase with age. Am J Obstet Gynecol 2012; 206: 349.e1-7.

27. Borowski D, Pietryga M, Basta P, Cnota W, Czuba B, Dubiel M, Fuchs T, Huras H, Iciek R, Jaczynska R, Kaczmarek P, Kosinski P, Kwiatkowski S, Nocun A, Pomorski M, Ropacka-Lesiak M, Rybak-Krzyszkowska M, Sieroszewski P, Węgrzyn P, Wiecheć M, Wielgoś M, Zimmer M. Rekomendacje Sekcji Ultrasonografii Polskiego Towarzystwa Ginekologów i Położników w zakresie przesiewowej diagnostyki ultrasonograficznej w ciąży o przebiegu prawidłowym - 2020 r. Ginekol Pol 2020; 91: 490-501.

\section{Address for correspondence:}

\section{Jakub Młodawski MD}

Collegium Medicum

Jan Kochanowski University

Kielce, Poland

E-mail: jakub.mlodawski@ujk.edu.pl 